Article

\title{
Education for Sustainable Development: Emerging Themes from Adopters of a Declaration
}

\author{
Ambika Zutshi ${ }^{1}$, Andrew Creed ${ }^{1, *}$ and Brian L. Connelly ${ }^{2}$ \\ 1 Department of Management, Deakin University, Geelong, 3220, Australia; ambika.zutshi@deakin.edu.au \\ 2 Raymond J. Harbert College of Business, Auburn University, Auburn, 36849, USA; bconnelly@auburn.edu \\ * Correspondence: andrew.creed@deakin.edu.au; Tel.: +61-3-55633511
}

Received: 30 November 2018; Accepted: 22 December 2018; Published: 29 December 2018

\begin{abstract}
Universities that sign the Talloires Declaration signify their commitment to education for sustainable development. This research explores whether the signification is a strategic desire to be seen to be doing the right thing, or a genuine commitment to enhancing sustainability and helping the environment. This semi-structured interview research involves communication with the sustainability managers in the majority of Talloires signified universities in Australia. Since Australia has a comparably high rate of commitment to the Talloires Declaration, the findings represent rich and deep insight into reasons and motivations that can inform the adoption process around the world. Applying institutional theory and related concepts of structuration, isomorphism, and signaling, the findings are analyzed to reveal the range of environmental initiatives and the underlying explanation of themes. Current strategies and future directions for universities are indicated. Findings are that higher education is a key mechanism in business and society for finding and harnessing knowledge-based solutions. The challenge is that institutionalization has created resistance to change through coercive, normative, and mimetic isomorphism, along with rhetoric. Structuration factors should be considered in the context of making positive changes for sustainability in the university sector.
\end{abstract}

Keywords: Talloires Declaration; universities; environmental management; interviews; institutional theory

\section{Introduction}

Universities around the world are trying to incorporate sustainable development into their programs and processes. Some have taken the bold step of collaborating with others and adopting external standards. One such standard, The Talloires Declaration (TD, and pronounced tāl-wār), is a symbolic statement in the higher education (HE) sphere that highlights the need for education for sustainable development and outlines areas for its implementation [1]. The TD is neither reportable nor enforceable and is akin to a statement of intent signed by the presidents and vice chancellors of universities, which sends a persuasive signal to stakeholders.

In this study, we examine the rationale and bring to light environmental initiatives implemented by TD signatory Australian higher education (HE) institutions (HEI). This declaration has been signed by over 500 university presidents in more than 50 of the world's 196 countries [2,3]. In Australia, there are 24 Talloires signatories, which is more than half of their established universities [4]. Therefore, Australia provides an opportunity for relatively rich exploration of the actions, agency, and structures that enable Talloires principles to be promoted and followed. The Australian context can serve as an important example for other developed economies and establish a benchmark for expansion of the sustainability declarations in the future. The reasons for Talloires Declaration adoption in Australia, 
and how its principles and actions are communicated, should be of interest to those recommending wider global uptake of this declaration and related creeds in support of sustainable practices in HE.

Our paper presents the findings of interviews with representatives of the Talloires signatories in the Australian HE sector. Concise background and description of the symbolism of the TD is provided as context with the urgent need for business and society to engage with education for sustainable development, especially in the light of accelerating monthly temperature spikes, unprecedented ice cap melts, exceptionally fierce bush fires, and dangerous atmospheric carbon concentrations [5]. Some research [6], in fact, criticizes large public sector organizations, including universities, for not being entrepreneurial enough (meaning innovative and responsive) to address unfolding environmental crises. The will to pursue Corporate Social Responsibility (CSR) in regard to sustainability is strong in both public and private sectors, but questions are being asked about mere rhetorical signification versus real outcomes in this space [6-8].

We use structuration theory [9] as a frame of analysis, since the institutionalization of sustainability occurs through the interplay between human agency and organizational structure. Focus is given to the view of Klein [10] that organizational actors (agents) signify concepts (such as sustainability) within and through domains of practice, while deferring the underpinning values in discourse and potentially changing them. Universities in Australia have demonstrated a propensity toward such signification [11], but further research could help uncover the underlying motivations for this phenomenon. The methodology in our paper focuses on the structuration elements universities manifest as they promote their public discourse about Talloires action points.

\section{Talloires Application and Theory}

TD is a symbol of education for sustainable development rather than a mandated or applied action tool (see Appendix A for TD 10 actions). Promotion of the Declaration by universities around the world is normally in combination with other reportable tools, such as certification via ISO14001 [12], GRI reporting, and internal strategic plans including sustainability plans, which may set key performance criteria for environmental protection. Many universities work with a portfolio of other statements and tools for promoting the virtues of behaving responsibly on environmental matters, including the European COPERNICUS Charter [13,14], the Magna Carta of European universities [15], the application of Ecological Footprint Analysis [16], and Eco-Management and Audit Scheme [17] certification. Within this mix, the TD, first composed in 1990 in Talloires, France, by 22 university presidents, remains the highest level and most widely-signed symbolic statement with a specific focus on education for sustainable development. As the list of assenting presidents has grown, so has the demand globally for education for sustainable development, which is now central to economic and environmental survival. Gumport [18] acknowledges the challenges for universities trying to legitimize their position amidst knowledge changes.

Structuration theory is a facet of institutionalization that helps explore the processes of establishing legitimacy for organizations. The theory suggests the structure of an organization serves to justify and reinforce its own existence through the agency of the people. Giddens [9] sees a fundamental interplay between human agency and social structure. Traditional practices, institutions, moral codes, and norms of behavior depend on and direct the structure of an organization. The interdependency creates systematization or institutionalization, and yet, it also implies the possibility of learning and change. Differences can be made by agents of change through symbiotic relationships with the structures and processes of the organization. Junaid, Leung, and Buono [19] (p. 492) explain that perceived legitimacy is important for organizations for competitive success and refers to "coercive isomorphism" being the social and political pressure to conform to perceived legitimacy. Masocha and Fatoki [20] find that coercive isomorphism, through policies, laws, standards, and regulations, is a significant driver of small businesses adopting, for example, initiatives related to sustainability. There are two other isomorphic types; one is mimetic, based on mimicking successful organizational structures and initiatives, and the other is normative, whereby expert views and influence become widely adopted [21]. 
Isomorphism is a concept borrowed from human ecology that was coined by DiMaggio and Powell [22] (p. 149), as "a constraining process that forces one unit in a population to resemble other units that face the same set of environmental conditions". The phenomenon helps explain why one university, for example, can look remarkably like another in many of its structures and processes. In an institutional context, the objectives, strategies, and even the people get recirculated and emulated to create the isomorphic effect, which serves to keep managers and staff comfortable that the whole operation is legitimate. For organizations, there is an implied dual mechanism-one aspect that can tend to homogenize the structural appearance of organizations to enhance social legitimacy and another that can promote legitimizing rhetoric about continuous improvement for competitive success. In the Australian university sector, the dual-edged isomorphism is among the features this research explores in the context of education for sustainable development. Castelló and Lozano [23] and Castelló and Galang [24] specify three approaches to legitimation: strategic, institutional, and political (or dialectical), in rhetoric statements by firms. Together, these have the effect of ensuring an accepted (homogenized) place in the perceptions of stakeholders. This effect must be counterbalanced with the genuine need to remain competitive and distinguished from other institutions at times of consumer choice. To this end, our study looks at the signaling [25] of environmental initiatives in the interview responses from participants in concert with public communication by each participant university surrounding the TD. Legitimation occurs at the level of the individual manager and across the broader organizational system. Since theory suggests the agency of champions for change is a natural part of the exploration of the structuration and signaling phenomena in Australian universities, we explore these facets.

In the case of education for sustainable development and the signing of the TD, the social imperative for involvement is strong and growing. Initiatives being implemented and publicly communicated by the universities reflect isomorphism. Sometimes, the underlying motivation may be to sustain the strategic and operational status quo, and other times it may be to make real differences in activity and outcomes for helping the natural environment. When Genus [26] discusses organizational behavior modification for better sustainability governance through principles, norms, and decision-making procedures, institutional theory is referenced along with rhetorical and isomorphic aspects of the case example. Furthermore, Patriotta, Gond, and Schultz [27] emphasize the public justification aspect of isomorphic re-structuration during times of institutional change. By acknowledging signification, rhetoric, and discourse in the public domain, research has indicated how both real and perceived changes may have a symbiotic relationship and suggests that legitimizing actions, such as the signing of the TD by universities, can be aligned with this theoretical field [28-31].

When agents or champions of change engage with public communication about sustainability, there is another dual aspect to consider-one that rhetoric is produced for strategic organizational (possibly personal) reasons and another that genuine social responsibility motivations are driving the communication. Where organizational transparency is high, Graafland and Smid [32] assert that genuine social responsibility motivations followed-up with well-managed implementation of environmental initiatives decrease the risks of a visible and harmful gap between rhetoric and reality. One element of our research in the Australian context is a snapshot of the interplay between what signatories of TD are doing and what they are signaling about their environmental initiatives [33]. Busch, Bauer, and Orlitzky [8] provide examples among financial institutions of the mismatch between environmental sustainability rhetoric and action. Thus, we believe it could be useful to explore in the words and deeds of university sustainability managers.

\section{Methodology}

This paper presents the findings of interviews with representatives of universities who had signed TD. Due to the exploratory objective, a qualitative research design was employed to conduct this research, as supported by Denzin and Lincoln [34]. The research design involved a subjective ontology in a qualitative, interpretive epistemological framework. Semi-structured, in-depth interviews 
garnered empirical data consistent with other qualitative studies in the sustainability literature [35,36]. Based upon the review of signatory websites in Australia, the elements of the Declaration the signified universities are choosing to highlight were identified, which were used to design a semi-structured interview template. Interview data were augmented by thematic tracking with NVivo theme analysis.

With respect to sampling, invitations for interviews were sent to relevant managers from all institutions that had signed the TD. There were 24 signatory universities at the time of data collection, of which 15 agreed to participate in the research. Environmental managers (or equivalent) from these Universities were interviewed, with each interview lasting approximately sixty minutes. All except two of the interviews were conducted at the premises of the interviewees. All were digitally recorded and subsequently transcribed. The transcriptions were sent back to interviewees for verification of content before being merged as part of the data analysis. The context of the interviews was understood to be managers discussing their institutional perspectives in relation to the TD and related initiatives. The personal nature of preferences and pride in initiatives was acknowledged and discussed in a few instances. In accordance with the qualitative and exploratory research design, this was assessed to be an appropriate way to gain a rich and deep analysis of situational factors. The limitations of the research were the lack of replicability and the subjective nature of some of the responses.

\section{Themes Emergent from the Interviews}

NVivo theme analysis revealed six emergent categories which enabled interview analysis to be grouped. The categories were: Initiatives (environmental) you are proud of; Benefits of being signatory to TD; Challenges of implementing TD; Structural changes and actions; Strategy, planning and stakeholder influences; and Future directions. These categories emerged partly from the framing of the semi-structured interview questions, but also from the NVivo process of extracting from the interview transcripts the main issues the managers talked about in their responses.

\subsection{Initiatives (Environmental) You are Proud of}

A wide range of initiatives were disclosed by Talloires signified universities. Some initiatives were implemented by all of the interviewed managers, while other specialized projects were identified for particular universities in the sustainability space. Talloires did not emerge as the primary driver for any single initiative during the interviews, although signing the declaration itself was classified as an initiative pursued at some moment by each university in the preceding years. The interviews revealed categories of environmental sustainability initiatives in the following areas:

- Buildings-New, retro fitting, or maintenance of infrastructure to make it more sustainable.

- Water-Collection of rainwater, monitoring and conserving of water usage. All the interviewees communicated a strong water research agenda.

- Recycling and waste management systems, and their subsequent planning and audits.

- Energy audits with focus on energy efficiencies. All the interviewees mentioned having formal energy implementation manager or equivalent responsibilities as part of another manager's portfolio in their respective universities.

- Transport related initiatives were generally included among other priorities as part of the sustainability plans

- Initiatives to commence or revise sustainability planning, reporting, or both, such as Global Reporting Initiative (GRI) or International Sustainable Campus Network (ISCN)

The majority of interviewed managers were the same or similar in publicly communicating these types of initiatives through media, websites, and targeted reports, thus suggesting an element of institutional isomorphism. Structurally, many of the initiatives in buildings, maintenance, recycling, and transport were aligned with facilities management departments, with some exceptions across the sample with these initiates been implemented from dedicated institutes. 
As a measure of the agency aspect of structuration, interviewees were asked to provide examples of the initiatives that they were proud to achieve and that they would highlight to their stakeholders. Examples included baseline standards achieved and aspirational environmental initiatives, each with measurable and operational targets as illustrated in words such as:

"I'm certainly proud of our commitment to renewable energy" (U2)

"Initiatives around sustainable transport which is a major contributor to the environment transport with the carbon emissions. So we feel really proud of what we've done in that area as well as all the other stuff that we've been doing, you know, the mega water tanks that are underground that you not even realize are there to capture the rainwater and use that for the toilets and that kind of stuff" (U4)

"Proud of getting sustainability into our buildings. The three new buildings are going for green star ratings" (U13)

Adherence to standards, as indicated by the third comment, was a coercive influence [20], which also had elements of normative isomorphism, since expert opinion encouraged standardization and also mimetic isomorphism [21], due to many of the other universities aiming for star ratings on their buildings.

Visible projects were causes for pride, which is to be anticipated given their contribution to social impact, whilst being measurable against strategic and sustainability objectives that the universities, and the individual change agents, had in place. It is from pride that an agency is at least partly motivated, and as Giddens [9] and Klein [10] suggest, the champions (agents) signify institutional priorities within and through domains of practice while deferring the underpinning values in discourse and potentially changing them. While the interviews did not specifically focus upon the concept of formal Environmental Management Systems (EMS), a number of cited initiatives assumed the characteristics of EMS [37,38]. For example, U6 managers described an integrated strategy for sustainability from the highest strategic plan through to divisions in the strategic pillars of teaching, research, and facilities or services. U2 and U1 also intimated systemic approaches to sustainability, the latter driven by a sustainability agenda dating back as far as the energy crisis of the 1970s. This was generally indicative of normative isomorphism, whereby a body of expert knowledge influenced the strategic approach taken.

\subsection{Benefits of Being Signatory to TD}

The structuration, rhetoric, and signification elements of institutional theory were explored by a question about benefits. Interviewees acknowledged the association and benefits from being TD signatory. The signing coincided in most cases with restructured divisions and departments, along with new processes to enable ongoing implementation of environmental initiatives as can be seen in the following excerpts:

"The benefits of being a signatory are that there is clear institutional support from a very high level that outlines an institution's commitment" (U12)

“We've got better processes around like our NGERS reporting, like the National Greenhouse and Energy Reporting" (U6)

"There are a couple of benefits there, I mean the obvious benefit is it saves the University money, but the by-product of saving money is that we reduce our carbon emissions" (U8)

Interviewees appeared to be asserting that efficient use of ever shrinking resources (for example, financial, human, and streamlined processes, when reporting across multiple measures) along with senior management support were the most useful structural factors to come from being a Talloires 
signatory. In alignment with the idealism side of signification, interviewees expressed satisfaction with being able to achieve certain benefits for the environment by association with Talloires and related initiatives. Positive feedback serves a purpose in the realm of public justification [27], which contributes to isomorphic re-structuration during times of institutional change.

On the rhetorical view, few interviewees were cognizant of how positive feedback from surveys, measurements, and publicity around initiatives served their personal strategic objectives and those of their organization. On balance, almost all the managers interviewed tended to idealism. This may be representative of a wider sentiment about the inherent joy of working in a field where genuine community benefit can occur. A sense of meaningfulness was present when they felt they were contributing to making the environment better for all. There may be lessons here for universities seeking to adopt TD in future, whereby the ability to tap into motivating sentiments for helping to mitigate climate change can potentially obviate some of the barriers to change.

\subsection{Challenges of Implementing TD}

Institutional theory explains the inherent resistance to creating organizational change [39,40]. Most managers were aware of the difficulties of asking people and systems to change. There was a sense of urgency about the fact that natural resources, air and water quality, and other ecological indicators are degrading faster than we can keep up. However, the human factors as barriers to making haste on mitigating climate change were noted to be real and resistant in pockets.

"So it's a bit of a challenge engaging with researchers in particular. Teaching's relatively straightforward, but the research side of it ... [has] ... to be carefully managed, and it actually takes up a lot of their time getting a project that actually fits all models" (U7)

"The challenges are that we work very much in operations and we would like to work more in teaching and learning and research" (U13)

"The biggest challenge is just awareness raising, to say we are doing stuff" (U5)

"The major challenges are I guess the organization embedding sustainability into its very being" (U10)

These comments appear to indicate that it was exasperating for some managers to find the time, people, and financial resources to do everything deemed important. Nonetheless, once priorities were set, the resource allocation process was clarified and that helped articulation with strategic planning cycles, as well as firming up the completion of established initiatives. Among the discussions at this point were acknowledgements of differences between universities. A problem or challenge in one place was not necessarily the same barrier in another. The challenges were contextual to the location of the institution, the types of people in charge, and the prevailing strategy and structure. It became clear through all of the interviews that the network of stakeholders was a crucial aspect of understanding and managing managerial responsibilities in the sustainability space in higher education.

Some ambivalence was present in the multi-campus universities about how best to integrate their sustainability initiatives, although the status quo was to include the regions in all discussions and measurements of outcomes, for example:

"The university has saved 1.8 million kilometers over the last 24 months in intercampus travel with our fleet cars because of some of the work we've been doing" (U4)

"We actually have far more rapid and enthusiastic adoption in sustainability thinking across the regional campuses. We have a lot more staff there that are far more prepared to engage with it" (U6) 
This represents an intra-organization perspective with signs of coercive and mimetic isomorphism between campuses. However, not all Talloires signatories have multi-campus operations, so the findings cannot be generalized in this research. Further research would be needed to fully account for multi and regional campus similarities and differences.

To ask about education for sustainable development and how universities themselves are handling change is a question of organizational development. These comments accentuate the importance of stakeholder consultation and involvement at all levels of the decision and action process. Stakeholders increasingly want universities to be leaders in education for sustainable development. To be signing Talloires and signaling the same to their stakeholders assists the institutionalization of sustainability concepts across campuses.

\subsection{Structural Changes and Actions}

Consistent with structuration theory, many of the interviewed universities had engaged in divisional or departmental restructure efforts to better serve a sustainability agenda. Some described cycles of restructure over a number of years. Others had made recent changes. All interviewees suggested there had been structural shifts consistent with the evolving social awareness of climate change, which had resulted in the emergence of new departments, divisions, or committees to promote sustainability initiatives. The interviewees indicated variances in relation to the following elements of the structural changes: frequency of changes; recency of changes; and scale and scope of changes.

"The person who was last in the position of environmental manager ... had very good networks within the campus with academics and local community ... Unfortunately her role wasn't continued ... and it was really just the position being put on hold while the organization restructured itself" (U10)

"[The university] ... is strictly (a) dynamic, (b) complex and diverse and, whilst less siloed now with the new structure, still tends to be siloed" (U3)

"You need to find out what your institution believes, what is material to that institution. It's not up to the environmental manager, or sustainability manager to decide for the university. The university must decide, and you'll know that by what its focus is. What is the focus for the university? It has to be that way" (U1)

“Measure it. If you don't know what's happening out there you are really struggling on making a difference. You can't do it alone so you need to create your networks and I haven't discussed it at great length, but there's 15 or 16 of us, but we can't do it alone. It's how much you can engage with the others" (U2)

These examples indicate a political, organizational development aspect to the implementation of Talloires recommendations. The coercive isomorphism between universities was noticeable, as was the expected resistance to changes. Any change to organizational structure was likely to encounter resistance. The tension between what must be done to help the environment in a practical and immediate sense and the questions and concerns individuals have about their power and roles within structural change were emerging in a dynamic fashion. Power and coercion through structural change was clearly in these comments. It was the Talloires Declaration that signaled political engagement and subsequent strategic and structural aspects of organizational change. The latter comment about measurement as a way to build networks and effectively carry change through to multiple institutions is a further example of both normative and coercive isomorphism [21].

\section{Reporting}

All of the interviewees attached high importance to being able to measure and evaluate the sustainability initiatives they were pursuing. The existence of positions and departments, and the 
attainment of funding for initiatives, were linked with the ability to appeal to stakeholders with accurate and meaningful data about activities and outcomes. This can indicate a purely rhetorical stance, or alternately, an understanding that feedback in communication systems is operationally important. In some cases, sustainability reporting required certain measurements, in others a set of key performance indicators (KPI's) were linked with broader sustainability objectives. Some suggested that TD is not reportable, but others suggested a range of reporting themes including:

- Global Reporting Initiative (GRI)

- $\quad$ Key Performance Indicators (KPI)

- Stakeholder surveys

From a structuration perspective, once an institution was committed to one or more of the reporting or survey regimes, this tended to determine the sources of data, lines of authority, and the divisional split of responsibilities in environmental initiatives. The standardization of requirements for reporting purposes, therefore, had an isomorphic effect across many of the institutions. Of interest was the non-reportable nature of the Talloires Declaration, making it effectively a signifier of intention rather than an applied tool of institutional structuration. Most of the managers did not feel there would be advantage in reporting against TD action points, instead preferring to leverage off its persuasive signaling feature to add weight to the reporting they were doing against the other measures.

\subsection{Strategy, Planning, and Stakeholder Influences}

The drivers of sustainable actions were readily discussed by interviewees. The three main directions of stakeholder pressure were from top down, to bottom up, and with community input, which we categorized as follows:

- Top down management

- $\quad$ Student-led initiatives

- Community-based drivers

Accordingly, significant webs of relational networks were driving and succeeding at environmental initiatives. Mapping of stakeholder inputs by sustainability managers was a key part of identifying the best ways to achieve the implementation of Talloires action items. Antithetical to isomorphic effects, the identification of influential stakeholders and networks seemed to give some institutions a point of difference and served as drivers of some initiatives that helped them to differentiate in the sector.

Sustainability for all of the interviewed universities occupied a strategic space, and there was a connection of sustainability initiatives with each of the three main pillars of university activity:

- Teaching

- Research

- Facilities/services

These three pillars were intertwined and integrated on successful partnerships input, and communication from stakeholders in various incarnations, dependent on the respective pillar. The institutions that strongly adopted sustainability as a strategic focus and integrated public communication in the most widespread way might be expected to have planning, accountability, and reporting centralized through the Chancellery rather than through the Facilities Management department as just one pillar. In practice, there were some examples of Facilities managers being genuine champions of key initiatives and the successes being widely communicated, celebrated, and integrated into future strategic plans by the Chancellery. Some excellent initiatives involving energy, transport, and buildings being integrated with academic and administrative divisions were found to be instigated by some Facilities managers and collaboratively implemented through the teaching and research pillars. Similar champions could be found in teaching and in research as agents and drivers of positive change. 


\subsection{Future Directions}

Overall, interviewees signaled an inevitability of change and improvements to sustainability practices in the higher education sector which may be due, in part, to the high-level support for change arising from signing the Talloires declaration.

"This university's going through a business improvement program as do other universities as well. The university is really focusing on its teaching, research and learning, and how that interacts with the operational side" (U1)

Therefore, regardless of challenges and resistance that might be expected, there were still some significant change programs being pushed through from the upper echelons for the university. The fact that grass roots support for genuine environmental action is often waiting for top-level signals on projects to help create positive change is probably helping this to occur, as evident from a few illustrative examples mentioned by the interviewees:

"Communities and people who have a passion to keeping this environment as it is or to enhance it in varied ways and we have the community groups that are both part and informed about the environment. We've got the infrastructure support services ... We have I.T. investment thinking about sustainable I.T" (U9)

"our annual report is designed in a TBL approach. But obviously that brings in lots of stakeholders across the university which I am one of, such as the core of the environmental sustainability, but our social inclusion and HR and student equity and all those other groups when you bring it together I think create quite a story around the university's TBL approach" (U2)

A sense of the gravity of the problem, exemplified by rising temperatures, more intense storms, melting ice caps, and higher $\mathrm{CO} 2$ concentrations in the air, was evident in all interviews. The mood often turned toward how the future would look in the higher education sector. Consensus was also noted about the role of the Talloires declaration in education for sustainable development, and the need for surveys of sustainability stakeholders in the university sector, for instance:

"Where we have the biggest impact as a higher education institution is in the dissemination of knowledge and learning and educating future generations of leaders, undertaking research into renewable energy, environmental management, environment science, environmental engineering" (U11)

“We worked with other students to do a survey asking what do students want in a bike hub?" (U15)

"We do the TEFMA environmental survey ... we also have an annual report. ... with our utility performance and energy and water consumption" (U13)

Sustainability managers expressed considerable concern for the wide ramifications of sustainable practices. This indicated that education for sustainable development, as a primary focus of the Talloires Declaration, was naturally embedded and thus likely to continue in the future. Sustainability managers pointed to the importance of measurement in order for actions to be achieved. Talloires was identified as symbolic and actionable only to the extent that a proactive university president (vice chancellor) embedded key performance indicators into strategic plans for the university. A sense of surprise sometimes emerged from interviewees when discovering the identities of the non-signatory universities in Australia. A number of interviewees knew these institutions, despite not signing, often still had very strong reputations for education for sustainable development by their diligent application and reporting of their initiatives. To some extent, this may be the case globally, for instance, 
those universities not signed up to TD may still have robust and successful sustainability initiatives established. Nonetheless, the Australian context is one where the TD is quite broadly recognized as a relevant signal of intent to care for the environment.

The unique blend of educators, administrators, and facilities staff in the higher education sector led to some mixed views about what the motivators for future action might include.

"And get the academics involved, because who are they influencing? Our future leaders. They're influencing the people that are going out there" (U1)

“The Talloires I thought was really influential in establishing ... we established new professorial position around education for sustainability and a lot of the language and discussion was around if we're going to commit to Talloires the teaching is really important" (U2)

These and similar comments suggest that Talloires appears to have been perceived as positive, but there were indications of uncertainty about why some members of the higher education staff are seen to be more resistant than others toward implementing change.

\section{Discussion}

The interviews found that organizational agents signal concepts, including sustainability and education for sustainable development, within and through domains of practice, while sometimes deferring the underpinning values in discourse and sometimes changing them. This finding is consistent with structuration theory and supports other research revealing universities in Australia have demonstrated a propensity toward signification of environmental initiatives [11]. While there is research in other countries suggesting adoption of the TD is perceived positively in the local community [41,42], the comparatively higher adoption of TD in Australia may be reflective of rhetorical and structural distinctiveness in the culture. In general, however, the increasing and worrying evidence of the effects of human-induced climate change is tending to motivate rhetorical shifts, at least, for institutions in most parts of the world. The institutional barriers to change at the global level remain as something to continuously and incrementally address. The interviews have exposed some of the underlying motivations for the Australian rate of TD adoption, such as the isomorphic effect in the structuration framework, stemming from institutional pressures derived from structure, process, governance, and the need to publicly signal certain strategic messages about sustainability.

Universities are obliged, on behalf of their stakeholders, to run their operations efficiently, effectively, and responsibly. A university may aspire to social or environmental objectives rather than the profit motive, but they still share the obligation to be efficient, effective, and well-governed [38-40]. Many of the interviewees also shared an individual commitment to mitigating climate change and felt a community spirit in conducting their roles, sometimes collaborating across institutional boundaries in spaces that would otherwise be strategically competitive. Networks, industry organizations, and conferencing opportunities were all mentioned as ways to voluntarily collaborate on environment-preserving objectives perceived to bigger than individuals or single universities. Talloires was also noted as a voluntary signification of intent, however, mandated institutional projects, reporting, systems, and procedures were seen as more effective for achieving sustainability objectives at the micro level.

ISO14001 is one way to voluntarily encourage EMS at universities to conform to a global standard. The research found a number of the Talloires signatory universities in Australia, in response to stakeholder pressures about climate change challenges, were promoting their adherence to sustainability plans and associated EMS plans, and some were publicizing the achievement of ISO accreditation. The trend to action beyond mere focus upon recycling and waste reduction seemed to be accelerating somewhat. The next step, encouraged by Talloires, of inculcating all of the education courses with the basic tenets of sustainability was less developed in all but a few universities. This 
appeared related to the notion of the three main pillars of teaching, research, and facilities and services standing as separate yet related structural elements. The separateness of the administration of teaching from that of research centers, for example, created institutional barriers to knowledge transfer between the pillars. Some universities were able to transcend such barriers through policy, process, and selection of appropriately skilled and passionate personnel.

The interviews revealed agency and structure around the sustainability issues highlighted by Talloires are symbiotic in Australian higher education. Champions of positive change do exist at many universities and there are many models, initiatives, benchmarks, and systems that already exist for positive isomorphic effects to take place. Isomorphism can have both positive and negative effects. If all universities are symbolically adopting Talloires and associated initiatives simply to conform to public perception of what should be happening, it is possible that what actually happens is not up to the required standard needed to make a substantive difference. A more positive isomorphism is manifest when genuine transmission of good ideas occurs and world standard initiatives are replicated across institutions. This research suggests a good proportion of the positive side is occurring, while some of the negative aspects appear to be occurring via signaling through various public communications without the full commitment of resources and support that would make the most of it. While this is the same for any kind of organization, for universities which are signified by Talloires, funded significantly by taxpayers, and have a social role to play through education for sustainable development, the imperative is strong to implement the Talloires ten action points authentically.

Nearly all the interviewees referred to the sustainability network as a forum for sharing ideas, and learning about other initiatives in the sustainability space. Signification, open communication, and feedback were all aspects of institutional knowledge and formed the basis of structuration and coordination in the subject universities. In practice, openness versus strategic silence were countervailing forces across the network of higher education institutions in Australia. U8, for instance, referred to the large solar energy generation project funded through U7, while the people at U7 were cognizant of the OSCA fully automated, on-site commercial "waste to compost" system at U8. Likewise, the U2 and U6 managers appeared well-versed with the initiatives of each other. Occasionally, however, it was evident that a strategic emphasis or direction at one institution was deemed a unique angle in the broader strategy to compete in the global higher education market, therefore, reducing a manager's prerogative to talk very openly about it. In practice, the sheer cost of investing in a large sustainability project, such as the U7 solar generation project, was a barrier in itself for other universities to compete, thus, allowing openness of the managers to discuss and promote the project. With sustainability in general and the Talloires Declaration in particular having strategic in addition to idealistic elements in the plans and aspirations of Australian universities, these dual edged outcomes had a foundation.

\section{Concluding Thoughts}

Creating and disseminating knowledge about mitigating climate change is an important concern. Higher education is a key mechanism in business and society for finding and harnessing knowledge-based solutions. The challenge is that institutionalization has created resistance to change through coercive, normative, and mimetic isomorphism, along with rhetoric. Structuration factors should be considered in the context of making positive change.

In the interpretive paradigm, reflection and hindsight are powerful aids to clarify how implementation (or communication) of initiatives can be improved moving forward; and how the same challenges can be reduced for peers. There was general agreement among the interviewees that successful university sustainability activity was dependent upon the people involved and the significance of networking, sharing and promoting good practice with a view to collective benefit. There was, however, a general acknowledgement that sustainability has a strategic value to individual institutions.

There is little reason to doubt the good will of the Presidents and Vice Chancellors who signed the Talloires Declaration and the various managers and staff at universities responsible for education 
for sustainable development. However, an institutional reality is that resistance to change due to isomorphism has been significant. From one perspective, if climate change mitigation strategies are to be successfully implemented at universities, environmental sustainability elements have to be incorporated at the strategic level as opposed to being assigned only to an individual or environmental team (see also [43]). Due to the nature of change, resistance will be encountered by the implementation team (see also [44-48]).

It was quite clear from the interviews that teaching, research, and facilities and services were the three main pillars of implementation, and the interplay between them determined whether initiatives would flow successfully, or become inhibited by some barrier. For example, education for sustainable development was often covered in teaching through coursework with highly engaged and motivated students and teachers, with those ideas and sentiments sometimes not conveyed effectively to the other pillars. Likewise, a passionate research team might have been working on sustainability solutions which sometimes did not transfer into taught material in classrooms or into projects implemented by facilities and services. Additionally, the facilities managers were also yearning for continuously improved ways to promote their initiatives to the whole university community and beyond.

Our research has indicated that barriers can be overcome by taking small initiatives that create marginal change and are easy to integrate into the daily functioning of an academic, administrator, or even a student. This will steadily increase acceptance of new methods for doing things when coupled with increased awareness of environmental conditions. In some areas at universities, the first steps were taken long ago and they are now in a position to make transformational leaps. It is, hence, imperative that valid reasoning (and where possible the final result) is provided for each change to bring about improved environmental practices. The quantity of landfill that was reduced with the introduction of paper recycling systems is one such measurable example. Based on human nature, and cultural, demographic, and behavioral differences, one has to accept a few outliers who will refuse to accept any justification and change their habits. In such instances, the energy of the environmental team or champion needs to be directed toward the greater good. Of course this energy shift will only occur once all education awareness methods (and if practical, rewards) have been effectively planned and implemented, and this sets the direction for further research around the world in universities irrespective of their signing of the Talloires Declaration.

Author Contributions: Conceptualization, A.Z. and A.C.; methodology, A.Z. and A.C.; validation, A.Z. and A.C.; formal analysis, A.Z. and A.C.; writing-original draft preparation, A.Z. and A.C.; writing-review and editing, A.Z., A.C., and B.C.; project administration, A.Z.; funding acquisition, A.Z. and A.C.

Funding: This research received internal research funding for data collection activity from the Faculty of Business and Law, Deakin University.

Conflicts of Interest: The authors declare no conflict of interest.

\section{Appendix A. The 10 Actions Agreed to by University Heads Who Sign the Talloires Declaration}

1. Use every opportunity to raise public, government, industry, foundation, and university awareness by publicly addressing the urgent need to move toward an environmentally sustainable future.

2. Encourage all universities to engage in education, research, policy formation, and information exchange on population, environment, and development to move toward a sustainable future.

3. Establish programs to produce expertise in environmental management, sustainable economic development, population, and related fields to ensure that all university graduates are environmentally literate and responsible citizens.

4. Create programs to develop the capability of university faculty to teach environmental literacy to all undergraduate, graduate, and professional school students.

5. Set an example of environmental responsibility by establishing programs of resource conservation, recycling, and waste reduction at the universities. 
6. Encourage the involvement of government (at all levels), foundations, and industry in supporting university research, education, policy formation, and information exchange in environmentally sustainable development. Expand work with nongovernmental organizations to assist in finding solutions to environmental problems.

7. Convene school deans and environmental practitioners to develop research, policy, information exchange programs, and curricula for an environmentally sustainable future.

8. Establish partnerships with primary and secondary schools to help develop the capability of their faculty to teach about population, environment, and sustainable development issues.

9. Work with the UN Conference on Environmental and Development, the UN Environment Program, and other national and international organizations to promote a worldwide university effort toward a sustainable future.

10. Establish a steering committee and a secretariat to continue this momentum and inform and support each other's efforts in carrying out this declaration.

Source: http://ulsf.org/wp-content/uploads/2015/06/TD.pdf.

\section{References}

1. Reid, J. Universities without Walls: Engaging Our World. High. Educ. Rev. 2013, 46, 31-51.

2. What Is the Talloires Declaration? Available online: http://ulsf.org/talloires-declaration/ (accessed on 21 December 2018).

3. Talloires Declaration Signatory List as of 1 July 2018. Available online: http:/ /ulsf.org/96-2/ (accessed on 21 December 2018).

4. Universities and Higher Education. Study in Australia. Available online: https:/ /www.studyinaustralia.gov. au/global/australian-education/universities-and-higher-education (accessed on 21 December 2018).

5. Global Climate Report. National Oceanic and Atmospheric Administration, National Centers for Environmental Information. Available online: http://www.ncdc.noaa.gov/sotc/global/ (accessed on 21 December 2018).

6. Engelke, H.; Mauksch, S.; Darkow, I.; von der Gracht, H. Heading toward a More Social Future? Scenarios for Social Enterprises in Germany. Bus. Soc. 2016, 55, 56-89. [CrossRef]

7. Dentchev, N. To What Extent Is Business and Society Literature Idealistic? Bus. Soc. 2009, 48, 10-38. [CrossRef]

8. Busch, T.; Bauer, R.; Orlitzky, M. Sustainable Development and Financial Markets: Old Paths and New Avenues. Bus. Soc. 2016, 55, 303-329. [CrossRef]

9. Giddens, A. New Rules of Sociological Method; Basic Books: New York, NY, USA, 1976.

10. Klein, V.H. Bringing values back in: The limitations of institutional logics and the relevance of dialectical phenomenology. Organization 2015, 22, 326-350. [CrossRef]

11. Zutshi, A.; Creed, A. Declaring Talloires: Profile of Sustainability Communications in Australian Signatory Universities. J. Clean. Prod. 2018, 187, 687-698. [CrossRef]

12. ISO Protecting Our Planet: ISO Standards for the Environment. Available online: http://www.iso.org/iso/ home/news_index/iso-in-action/climate_change.htm (accessed on 21 December 2018).

13. COPERNICUS: The University Charter for Sustainable Development. Available online: https://www.iauhesd.net/sites/default/files/documents/copernicus.pdf (accessed on 21 December 2018).

14. Price, T. Preaching what we Practice: Experiences from Implementing ISO 14001 at the University of Glamorgan. Int. J. Sustain. High. Educ. 2005, 6, 161-178. [CrossRef]

15. Delakowitz, B.; Hoffmann, A. The Hochschule Zittau/Gorlitz Germany's First Registered Environmental Management (EMAS) at an Institution of Higher Education. Int. J. Sustain. High. Educ. 2000, 1, 35-47.

16. Venetoulis, J. Assessing the Ecological Impact of a University: The Ecological Footprint for the University of Redlands. Int. J. Sustain. High. Educ. 2001, 2, 180-196. [CrossRef]

17. Welcome to EMAS! Eco-Management and Audit Scheme. Available online: http://ec.europa.eu/ environment/emas/index_en.htm (accessed on 21 December 2018).

18. Gumport, P. Academic Restructuring: Organizational Change and Institutional Imperatives. High. Educ. 2000, 39, 67-91. [CrossRef] 
19. Junaid, N.; Leung, O.; Buono, A. Institutionalization or Decoupling? An Exploratory Analysis of the UN Global Compact LEAD Initiative. Bus. Soc. Rev. 2015, 120, 491-518. [CrossRef]

20. Masocha, R.; Fatoki, O. The Impact of Coercive Pressures on Sustainability Practices of Small Businesses in South Africa. Sustainability 2018, 10, 3032. [CrossRef]

21. Choi, M.; Lee, J.; Hwang, K. Information Systems Security (ISS) of E-Government for Sustainability: A Dual Path Model of ISS Influenced by Institutional Isomorphism. Sustainability 2018, 10, 1555. [CrossRef]

22. DiMaggio, P.; Powell, W. The Iron Cage Revisited: Institutional Isomorphism and Collective Rationality in Organizational Fields. Am. Sociol. Rev. 1983, 48, 147-160. [CrossRef]

23. Castelló, I.; Lozano, J. Searching for New Forms of Legitimacy through Corporate Responsibility Rhetoric. J. Bus. Ethics 2011, 100, 11-29. [CrossRef]

24. Castelló, I.; Galang, R. Looking for New Forms of Legitimacy in Asia. Bus. Soc. 2014, 53, 187-225. [CrossRef]

25. Bergh, D.; Connelly, B.; Ketchen, D.; Shannon, L. Signaling Theory and Equilibrium in Strategic Management Research: An Assessment and a Research Agenda. J. Manag. Stud. 2014, 15, 1334-1360. [CrossRef]

26. Genus, A. Governing Sustainability: A Discourse-Institutional Approach. Sustainability 2014, 6, $283-305$. [CrossRef]

27. Patriotta, G.; Gond, J.; Schultz, F. Maintaining Legitimacy: Controversies, Orders of Worth, and Public Justifications. J. Manag. Stud. 2011, 48, 1804-1836. [CrossRef]

28. Suchman, M. Managing Legitimacy: Strategic and Institutional Approaches. Acad. Manag. Rev. 1995, 20, 571-611. [CrossRef]

29. Suddaby, R.; Greenwood, R. Rhetorical Strategies of Legitimacy. Adm. Sci. Q. 2005, 50, 35-67. [CrossRef]

30. Sylvestre, P.; McNeil, R.; Wright, T. From Talloires to Turin: A Critical Discourse Analysis of Declarations for Sustainability in Higher Education. Sustainability 2013, 5, 1356-1371. [CrossRef]

31. María Brito, R.; Rodríguez, C.; Luis Aparicio, J. Sustainability in Teaching: An Evaluation of University Teachers and Students. Sustainability 2018, 10, 439.

32. Graafland, J.; Smid, H. Decoupling Among CSR Policies, Programs, and Impacts: An Empirical Study. Bus. Soc. 2016. [CrossRef]

33. Connelly, B.L.; Trevis Certo, S.; Duane Ireland, R.; Reutzel, C.R. Signaling Theory: A Review and Assessment. J. Manag. 2011, 37, 39-67. [CrossRef]

34. Denzin, N.K.; Lincoln, Y.S. The SAGE Handbook of Qualitative Research, 5th ed.; SAGE Publishing: Los Angeles, CA, USA, 2018.

35. Thellbro, C.; Bjärstig, T.; Eckerberg, K. Drivers for Public-Private Partnerships in Sustainable Natural Resource Management-Lessons from the Swedish Mountain Region. Sustainability 2018, 10, 3914. [CrossRef]

36. Hayden, A.; Wilson, J. Taking the First Steps beyond GDP: Maryland's Experience in Measuring “Genuine Progress". Sustainability 2018, 10, 462. [CrossRef]

37. Zutshi, A.; Sohal, A. A Study of the Environmental Management System (EMS) Adoption Process Within Australasian Organisations: Role of Stakeholders. Technovation 2004, 24, 371-386. [CrossRef]

38. Zutshi, A.; Sohal, A.; Adams, C. Environmental Management System Adoption by Government Departments/Agencies. J. Public Sect. Manag. 2008, 21, 525-539. [CrossRef]

39. Larrán, M.; Herrera, J.; Andrades, F. Measuring the Linkage between Strategies on Sustainability and Institutional Forces: An Empirical Study of Spanish Universities. J. Environ. Plan. Manag. 2016, 59, 967-992. [CrossRef]

40. Waddell, D.; Creed, A.; Cummings, T.; Worley, C. Organisational Change: Development and Transformation, 7th ed.; Cengage Learning: South Melbourne, Australia, 2019.

41. Hernandez, P.M.; Vargas, V.; Paucar-Cáceres, A. Education for Sustainable Development: An Exploratory Survey of a Sample of Latin American Higher Education Institutions. In Implementing Sustainability in the Curriculum of Universities; Leal Filho, W., Ed.; World Sustainability Series; Springer: Cham, Switzerland, 2018; pp. 137-154.

42. Adams, R.; Martin, S.; Boom, K. A Conceptual Framework for Designing, Embedding and Monitoring a University Sustainability Culture. In Handbook of Sustainability and Social Science Research; Leal Filho, W., Marans, R., Callewaert, J., Eds.; World Sustainability Series; Springer: Cham, Switzerland, 2018; pp. 465-482.

43. Kelly, M.; Bather, A. Corporate Social Responsibility and the Teaching of Management Accounting. Philos. Manag. 2013, 8, 15-26. Available online: https://hdl.handle.net/10289/4929 (accessed on 21 December 2018). [CrossRef] 
44. Ross, J.; Ross, J.; Creed, A. Corporate Ethics and Values: Guiding Business out of the Maelstrom. In International Business, Sustainability and Corporate Social Responsibility (Advances in Sustainability and Environmental Justice, Volume 11); Gonzalez-Perez, M.A., Leonard, L., Eds.; Emerald Group Publishing Limited: Bingley, UK, 2013; pp. 1-35.

45. Zhang, D.; Swanson, L. Social Entrepreneurship in Nonprofit Organizations: An Empirical Investigation of the Synergy between Social and Business Objectives. J. Nonprofit Public Sect. Mark. 2013, 25, 105-125. [CrossRef]

46. Carpenter, D.; Meehan, B. Mainstreaming Environmental Management: Case Studies from Australasian Universities. Int. J. Sustain. High. Educ. 2002, 3, 19-37. [CrossRef]

47. Taddei-Bringas, J.; Esquer-Peralta, J.; Platt-Carrillo, A. ISO 14001 and Sustainability and Universities: A Mexican Case Study. Manag. Environ. Qual. Int. J. 2008, 19, 613-626. [CrossRef]

48. Shang, S. Dual Strategy for Managing User Resistance with Business Integration Systems. Behav. Inf. Technol. 2012, 31, 909-925. [CrossRef]

(C) 2018 by the authors. Licensee MDPI, Basel, Switzerland. This article is an open access article distributed under the terms and conditions of the Creative Commons Attribution (CC BY) license (http://creativecommons.org/licenses/by/4.0/). 